
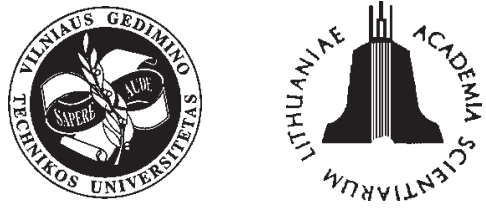

ISSN 1392-3730

JOURNAL OF CIVIL ENGINEERING AND MANAGEMENT

http:/www.jcem.vgtu.lt

2005, Vol XI, No 1, 73-82

\title{
ANALYSIS OF SUPPLY SYSTEM MODELS FOR PLANNING CONSTRUCTION PROJECT LOGISTICS
}

\author{
Anna Sobotka, Agata Czarnigowska \\ Faculty of Civil and Sanitary Engineering, Lublin University of Technology, ul. Nadbystrzycka 40 20-618 Lublin, \\ Poland.E-mail: hanka@akropolis.pol.lublin.pl; a.czarnigowska@pollub.pl
}

Received 17 Dec 2004; accepted 15 Feb 2005

\begin{abstract}
The paper discusses a number of construction project logistics problems, with focus on supply systems, and presents the results of recent survey of Polish contractors' supply routines. On the basis of the survey, patterns of development of logistic systems have been described. The enclosed results of cost simulations indicate that outsourcing supply logistic processes, considering the current state of Polish construction market, may reduce costs. The paper emphasises that creating logistic guidelines of a project at its early stages of planning and then a design of integrated logistic service to the project may help find ways of making a construction project more effective.
\end{abstract}

Keywords: logistics, material acquisition cost, construction project, supply system, logistic centre.

\section{Introduction}

Materials supply is an important element of operation of construction enterprises and thus a factor affecting the quality of construction projects. The level of materials costs reaches up to $70 \%$ of total construction cost estimations, therefore any actions towards rationalisation of size, structure and organisation of material consumption, delivery and planning are important in terms of project efficiency and require proper management.

Many industries attempt to integrate logistic processes into logistic chains of suppliers and customers, starting with obtaining raw material, through manufacturing, distribution and final sale and service to the endusers. Logistic processes, being crucial for successful completion of the project but in fact auxiliary, are often entrusted external professionals specialised in logistic services, such as logistic centres [1-3] and this tendency is also observed in construction.

In the field of construction, supply (ordering, transport and storage) and production dominate the logistic processes [18, 20, 24, 25]. Supply and production are often difficult to separate due not only to organisational but also technological reasons (considering eg erection of in-situ concrete structures and ready-mixed concrete deliveries). Traditionally, contractors taking part in a project were responsible for their individual supply chains to provide materials and services required within their scope of works. At the present time of well-developed market for building materials and services, centralising and outsourcing the project supply logistics is considered to be a more efficient solution facilitating the project control.

A variety of systems and strategies of logistics are used by enterprises. The choice of a logistic model implemented in a project should be based on careful analysis of the suppliers market limitations, structure of material consumption, accuracy of consumption planning and logistic cost minimisation. Also the scope and complexity of the project and its procurement system have a considerable impact on the logistic arrangements. The construction procurement systems evolve and "traditional" systems such as general contracting are often replaced by PM systems, where the manager acting on behalf of the employer decides on designers, contractors and suppliers selection [23]. Along with procurement system development, the constellation of decision-makers changes. For example, the choice of materials, their manufacturers or even suppliers belongs no longer to the designer or the contractor, but to the employer or his consultants or project managers. The latter decide also on the logistic system on the building site.

Deciding on project logistics requires a wide knowledge of the building materials market, financing, managing contractors' approaches to supply, and a deep understanding of the logistics impact on the project efficiency in terms of cost, quality and time. It is of great importance to be aware of logistic costs and their relationship to the model of logistics and assumed decision variables such as batch size, place and time of the delivery. These 
depend on current market conditions such as cost of capital, material and transport prices, storage costs and possibilities, safety and environment protection law [20].

The paper discusses a number of aspects of logistics with regard to a construction company as an organisation and as a participant in a construction project. It is based on the results of recent research on patterns of development of logistic systems in Polish construction enterprises. The enclosed calculations of logistics expenses present the impact of logistic system on costs. Two problems have been analysed: the first consists in the method of isolating logistic costs from the total cost account of a project or a company and in determining or estimating their value according to the logistic model. The second problem is the choice of supply system for a contractor taking part in a project that involves many contractors, based on material supply costs evaluation. Conclusions of the analysis of the above problems allow substantiating the integration of logistic tasks under a logistic management unit within the project organisation structure in the form of an internal or external logistic organisation. The responsibility of this organisation would be planning and co-ordination of material supply processes at each stage of the project, from the initial planning and design to execution and commissioning. The scope of responsibility of such an organisation may be wider and include management of flows of resources other than materials (equipment, staff and workforce, finance, information), and not only supply but also production.

\section{Logistics and supply chains in construction}

The term "logistics", as used in the title of the paper, is related to the term "supply chain". The meanings of both evolve and the attempts to classify these changes may be traced in numerous publications. In general, there are two approaches: the "traditional" and the "modern" schools of logistics and supply chain management [7]. In the traditional approach to logistics, the efficiency of logistic chains is improved by means of reducing inventories of resources. The modern logistics becomes a pervasive and unitary framework for supply chain management and emphasises the importance of co-ordination between physical and information flows. From the point of the current approaches, all cooperating entities (enterprises), or at least strategic partners are considered to form supply chains that are managed by means of modern management tools and techniques developed specifically for them. Therefore, logistics as a key concept may be understood variously:

- as a system of resource (ie material, workforce, information, funds, etc) flows from the supplier to the customer;

- as a philosophy of managing the processes of goods and information flows, based on an integrated and systematic approach to these processes, called logistic processes;
- as a branch of knowledge based on economics, technology and IT that investigates the relations and patterns of goods and information flows in the economy and economic organisations.

In 1992 the European Committee of Standardisation defined logistics as follows: logistic comprises planning, organising and control of flows of goods from their purchase, through processing to distribution to the end user, in order to fulfil market requirements and by minimal cost and minimal capital engagement [15].

Between the producer and the ultimate customer there are often many intermediaries such as wholesalers, retailers, shipment companies etc who, together with the former constitute a logistic chain. Management of logistic chains is aimed at tightening cooperation between its members. Integration and coordination is to enable using the improvement of each member to the advantage of whole process and optimising the value added by each member of the chain to the good or service offered to the customers according to their expectations [10]. Extending this philosophy over all functional fields of cooperating enterprises allowed to define the current approach of supply chain. This concept has a broader meaning than logistic chain as the latter focuses mainly on logistic tasks and processes.

The definition of supply chain and supply chain management with regard to construction was defined, among others, by Christopher: "the network of organizations that are involved, through upstream and downstream linkages, in the different processes and activities that produce value in the form of products and services in the hands of the ultimate customer [26] and by Love et al [13]: "the network of facilities and activities that provide customer with economic value to the functions of design development, contract management, service and material procurement, material manufacture and delivery, and facilities management".

The term "supply chain management" has been used not only with regard to the logistics activities and the planning and control of materials and information flows internally within a company or externally between companies. Some authors have used it to describe strategic, inter-organisation issues, others - vertical integration or relationship between a company and its suppliers [8]

There are not many publications on logistic processes and supply chain management in construction projects, and evidence of practical implementation of the supply chain philosophy is scarce. This is due to the fact that the processes of supplying a building site with materials are considered not different from supply processes in other industries, while logistic processes taking place on the building site are regarded as integral part of construction works. However, special features of construction supply chains as their temporariness and problems arising from the fact that each project is in fact a prototype are often recognised [26]. 
The concept of supply chain management is more often adopted to analysis and control of construction project management where the project's participants are seen as supply chain members. The authors of [13] claim that implementing the supply chain concept could be a remedy for low efficiency of construction enterprises that often suffer from schedule and cost overruns, quality deviations and poor health and safety. They present a "seamless" project supply chain management model that integrates the design and production processes of construction project with focus on integrating members of supply chain, cooperation, learning and benchmarking. Also Kumaraswamy et al [12] regard construction projects as supply chains and create a model of a decision support system aimed at improvement of procurement processes. Matthews et al [14] propose a method of improving effectiveness of construction processes and supply chains focusing on partnering, quality assurance and lean production approach.

Despite potential benefits from applying supply chain management to construction projects, there occur problems with its practical implementation. Dainty et al [9] studied this matter and defined barriers to supply chain integration for subcontractors and possible solutions. A focus on logistic aspects of supply management was presented in [6], where necessity and benefits of reengineering of construction project supply chains were stressed. A project is served by many logistic chains supplying a variety of resources.

The changes in logistic systems of construction material supply were described in [24], where adoption of different strategies for supplying different types of materials (case study for prefabricated components and ceramic products supply). Many researchers emphasise the importance of using IT/EDI/IS systems, which not only improve the information exchange and coordination of project participants' actions [5] but also help reduce transaction cost [25]. Many authors agree that implementing supply chain concept and logistic management to construction is a slow process. Most of construction projects are reported to be carried out in "traditional" way $[13,24]$, so that even the JIT concept, a basic method of logistic management, finds little application. Some exceptions to this statement are presented in [16].

In the following sections, construction material supplies are considered in a narrower aspect of logistic chains. The analyses focus on logistic processes and models of supply system of construction projects and organisations involved in them.

\section{Logistic processes by Polish contractors - a survey}

The analysis of results of a survey conducted in 1996-2004 among Polish construction enterprises allows to describe some patterns of logistics in construction and changes in supply routines. The survey covered: sources of supply, delivery contract routines, criteria of suppli- ers selection, reasons of delivery inaccuracies, bases of material demand forecast and distribution of responsibility for supply decisions. Two groups of contractors were interviewed: one group originated from the Lublin region (south-eastern Poland) [21], the other comprised 14 companies from the 100 listed as the best performing Polish contractors (www.muratorplus.pl) who responded to the survey [11]. In case of the latter, the survey was conducted by the end of 2003 and the beginning of 2004, the respondents were active on the construction service and trade markets and all of them were ISO quality standard certified.

Fig 1 presents an average share of value of purchase according to supply source. There is a tendency of decreasing direct purchase from manufacturers for the benefit of wholesalers. This is related to other tendencies of reducing own transportation and using suppliers' delivery services. Manufacturers often concentrate on production and offer no transport services.

a)

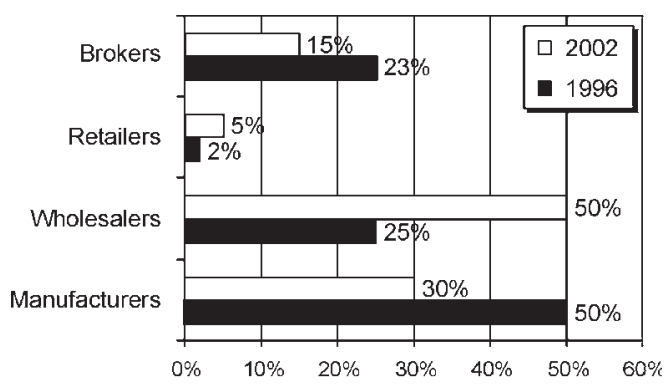

b)

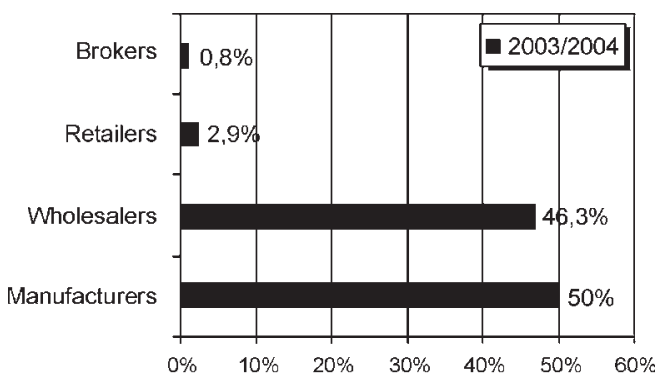

Fig 1. Share of value of purchase according to the type of supplier: a) survey of companies from Lublin region, b) survey of 14 companies from the list of best performing 100 in Poland

In most cases, delivery contracts concern single enterprises and there are no exclusive suppliers, but a longtime co-operation with a number of suppliers occurs very often. Such partnership allows the contractor to negotiate better terms of contract. The long-time contracts regard usually selected ranges of goods. Fig 2 shows the proportion of long- and short-time delivery contracts.

The co-operation between contractors and suppliers tends to grow. The suppliers offer additional services of warehousing and deliver on request in batches. Each batch may be paid separately. 


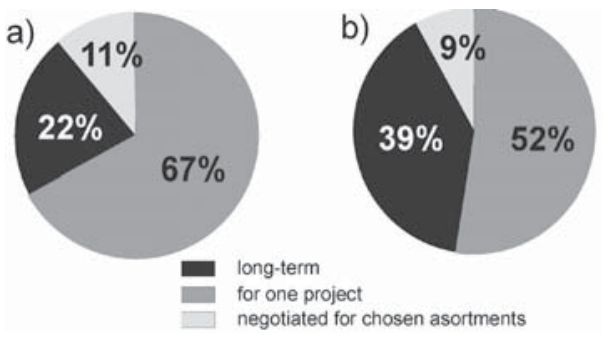

Fig 2. Distribution of long- and short-time delivery contracts: a) survey of companies from Lublin region, b) survey of 14 companies from the list of best performing 100 in Poland

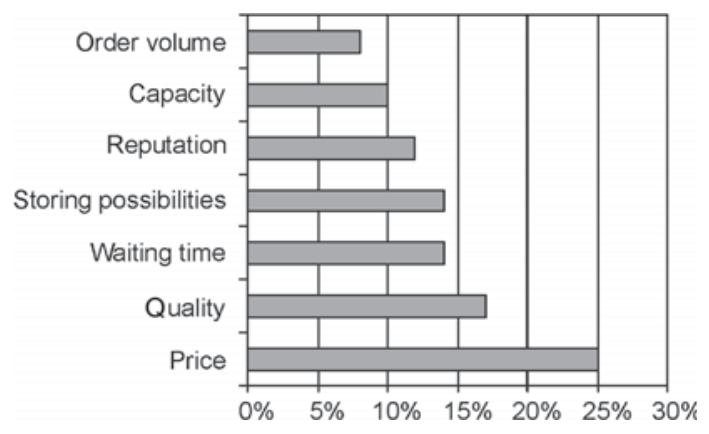

Fig 3. Criteria of supplier selection

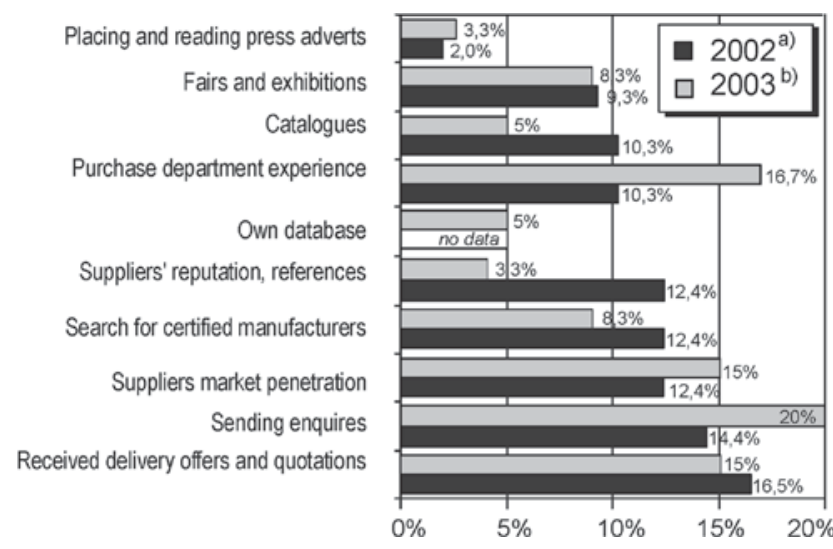

Fig 4. Methods of supplier acquisition a) survey of companies from Lublin region, b) survey of 14 companies from the list of best performing 100 in Poland

Criteria of supplier selection are presented in Fig 3. Fig 4 shows methods of supplier acquisition.

Delivery inaccuracies occur quite often in spite of the market domination of the consumer. Basic grounds of them are financial difficulties caused by employer's delay of payment and change of sequence of works on the building site. Further reasons are errors in the design, in orders, difficulty in obtaining uncommon materials. Typical supplier failures such as problems with transport are rare.

The contractors from Lublin region forecast their material demand on the basis of the construction sched- ule $(57 \%)$, the bill of quantities (14\%) and experience (29\%). Among the contractors from the list of 100 best prospering in Poland, the proportions are different: schedules are the most common basis of material consumption forecast $(80 \%)$, the bills of quantities help $10 \%$ establish the material demand and $10 \%$ base on experience. According to all respondents, the size of deliveries is dictated most often by the estimations of the construction manager, but it also depends on the capacity of the available means of transport, financial capability and project or delivery schedule. As for distribution of responsibility for logistic decisions in construction companies, there are usually a number of decision-makers. Their scope of operation differs according to the organisation structure of the company, but, in general, most of the decisions are taken by construction managers and purchasing departments (Fig 5).

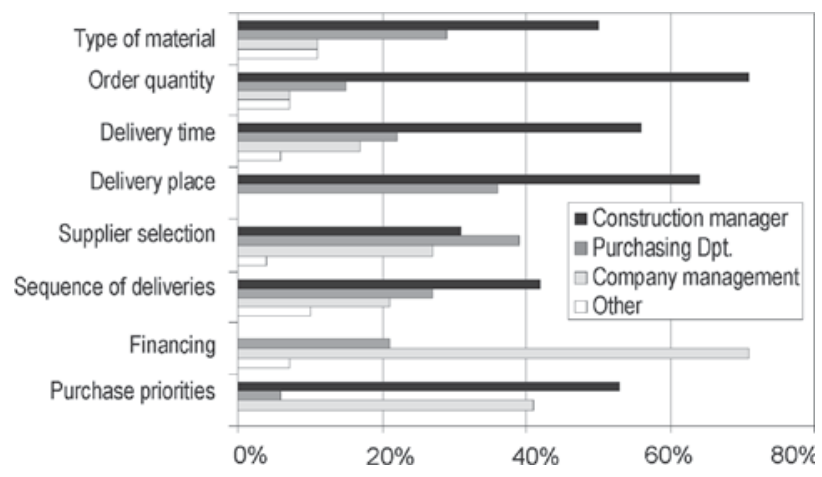

Fig 5. Scope of responsibility for logistic decisions, survey of contractors from the list of 100 best performing in Poland, 2004

The results of the survey point also changes in the contractor's supply system, consisting in reduction of the scope of logistics tasks performed by the own departments. Firstly, own transport and warehousing are being kept to a minimum. Secondly, processes connected with information flows, eg supplier selection, are being limited. Only about one fourth of respondents of 2004 survey kept buffer stocks of materials and only few types of materials were bought once in amount of their total consumption in the project.

Some tasks and functions connected with supplying the project with materials are often taken over by the members of the external logistic chains such as transport companies, wholesalers or manufacturers. Stocks stored traditionally on building sites are often kept by suppliers and delivered on request in batches. The project management, designers or even employers often select materials and suppliers. Also the project management, hired logistics professionals or specialised wholesalers take over supply planning and scheduling. Therefore, more actors are involved in a construction project. The relations between them evolve continuously (Fig 6) and further specialisation is to be observed [3,4].

Currently, the employer dominates the highly competitive construction markets and his decisions are bind- 

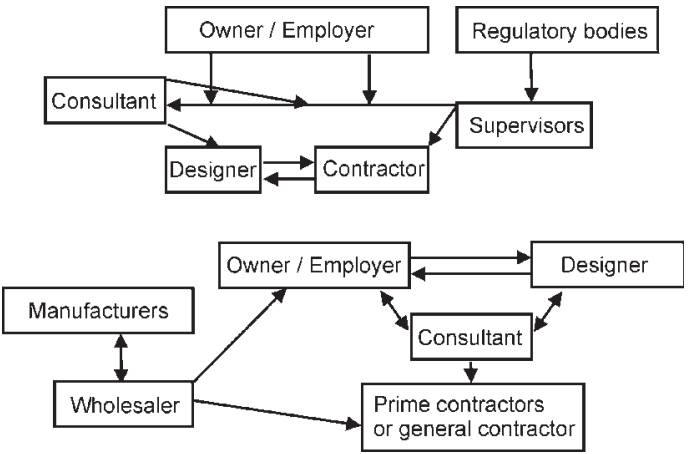

Fig 6. Relations among members of a project's supply chain [4]

ing for any actions of designers, contractors and suppliers, which reflects in the network of relations of the project's actors. The ultimate model of relations depends also on the project delivery system.

\section{Estimation of logistic cost according to supply model}

The three most often used criteria of projects' logistic system apprisal are quality, time and cost. The last criterion is considered to be the most important. This section assesses supply models according to cost for the following examples:

- Example 1: Analysis of standard logistic models and estimation of related material acquisition costs;

- Example 2: Estimation of logistic costs of two models of construction project supply, the project involves a number of independent contractors.

All prices, discount rates for bulk purchase, storage, transport and unloading costs and charges and other parameters assumed for these calculations were based on real market conditions in Lublin region as described below. The results of Example 1 calculations allowed to determine the model of the lowest total logistic cost and use it as a basis of building the model of a project's logistic service system.

\section{Example 1}

The reference point of the cost calculation in the analysed logistic models are routines of estimating logistic cost in bills of quantities (so called "detailed" method), commonly used in Poland. The costs of physical flows of goods and related information appear in Polish bills of quantities in two forms: buying costs and indirect costs (overheads). Buying costs include the cost of transport and unloading and are usually estimated as a fraction of total material direct costs (the same fraction for all materials, or more often, separately for each material) - in this case they appear as a separate cost group in the bill of quantities, or the buying costs are included in the price of materials. The overheads in the bill of quantities comprise general administration costs and indirect costs of the particular project, thus includ- ing costs of physical flows of goods and related information.

Calculations presented in this paper concern costs of materials consumed in large quantities, regularly and continuouslly for a longer period. Rationalisation of their flows may bring considerable savings. The basis of cost calculation is the general schedule of the project and the schedule of material consumption, derivated from the former. The project is construction of three multistorey residential buildings. The following models of supply system were analysed:

- Model 1: Deliveries directly to the building site, the batch size estimated as Economic Order Quantity modified by allowing for the load capacity of vehicles;

- Model 2: Deliveries directly to the building site, the batch size determined by the planned consumption - according to the schedule, a just-in-time delivery;

- Model 3: Deliveries to an auxilary stacking yard, from which batches of the material are taken to the building site regularly.

The batch size in the first model is calculated as follows:

$$
d=\sqrt{\frac{2 M \cdot k_{d}}{k_{u}}},
$$

$d$ - batch size,

$M$ - total demand for the material,

$k_{d}-$ cost of placing order and accepting delivery per order,

$k_{u}$ - unit cost of keeping inventory.

For each of the three models it was assumed that batches are equal in size, only the last one may be smaller to match the sum of total demand. Moreover, each batch was assumed to be treated as a separate order in terms of ordering cost and bulk discounts.

The acquisition costs of the three above models comprise, apart from costs of logistic processes, also direct material costs. This was to allow for bulk discounts in the calculations. The cost function [11]:

$$
\begin{gathered}
K=K_{L}+K_{B} \\
K_{L}=k_{i d} \cdot l_{d m}+k_{t z} \cdot l_{s}+k_{t w} \cdot l_{d b}+c_{j} \cdot p \cdot\left(s_{c}+s\right)+ \\
k_{t z} \cdot l_{b z}+K_{m}, \\
K_{B}=c_{j} \cdot M-c_{j} \cdot p_{u} \cdot\left(M-d_{u}\right),
\end{gathered}
$$

$K$ - total material acquisition cost

$K_{L}-$ logistic cost

$K_{B}$ - direct cost of material

$k_{i d}-$ cost of placing order \& accepting delivery, per order

$l_{d m}-$ number of orders (batches)

$k_{t z}-$ cost of external transport per vehicle run

$1_{\mathrm{s}}$ - number of external transport vehicle runs

$k_{t w}-$ cost of internal transport per vehicle run

$l_{d b}$ - number of internal transport vehicle runs 
$c_{j}-$ unit price of material

$p$ - cost of capital frozen in inventory

$s_{c}$ - average volume of inventory in warehouse

$s$ - average volume of inventory on building site

$k_{t z}-$ penalty for each day of delay

$l_{b z}$ - number of days of delay due to material shortage

$\mathrm{K}_{\mathrm{m}}$ - average fixed cost of keeping inventory

$M$ - total demand for the material

$p_{u}-$ bulk discount rate

$d_{u}$ - quantity of material bought without discount

There is no account for costs of material shortage in the calculations as it was assumed that the stocks were monitored. The parameters and variables are deterministic.

The results of the above estimations confirm the relationship between the model of supply and cost of material acquisition and allowed quantitative comparison.

According to the calculations, the costs of the economic order quantity model are significantly lower than costs of two other models. The "cheapest" model assumed that the delivered material was stored on the building site, which is relatively inexpensive as these particular materials require no special storing conditions, but it is space-consuming.

The Just-in-Time model, in this particular case, proved to be the most expensive. It is commonly used though, as the suppliers offer favourable purchase conditions: usually, the delivery agreements concern the total ammount of material required for the project and are discounted as a whole, not separately for each larger batch delivered.

As for the third model, there are currently no reasons for keeping large inventories of construction materials. As the survey confirmed, Polish contractors avoid keeping stocks. The supply exceeds demand and materials are readily available in wide choice, and prices are relatively stable.

Assuming that the parameters of the formula (3) allow for each element of logistic cost that occur in practice, the results of calculations presented in Table 1 indicate that an efficient management of material flows may bring considerable savings.

\section{Example 2}

There is an another calculation of material acquisition cost. The material is assumed to be used by 3 independent contractors involved in one project. To simplify the problem, calculations concern supply with only one type of material.

The method of calculation is similar to Example 1, but material consumption and delivery times are stochastic variables. A simulation of material acquisition costs was made separately for two supply models:

1) three contractors use the service of one entity offering logistic services,

2) the contractors supply themselves individually.

Table 1. Calculation of acquisition costs

\begin{tabular}{|c|c|c|c|c|c|c|c|c|c|}
\hline Parameters and variables & Model 1 & Model 2 & Model 3 & Model 1 & Model 2 & Model 3 & Model 1 & Model 2 & Model 3 \\
\hline Material & \multicolumn{3}{|c|}{ Blocks MAX-220 } & \multicolumn{3}{|c|}{ Foamed polystyrene FS 20} & \multicolumn{3}{|c|}{ Ceramic bricks } \\
\hline Discount by deliv. exceeding & \multicolumn{3}{|c|}{5000 pieces } & \multicolumn{3}{|c|}{$30 \mathrm{~m}^{3}$} & \multicolumn{3}{|c|}{1050 pieces } \\
\hline Load capacity of the vehicle & \multicolumn{3}{|c|}{1900 pieces } & \multicolumn{3}{|c|}{$57 \mathrm{~m}^{3}$} & \multicolumn{3}{|c|}{6650 pieces } \\
\hline$M$ & \multicolumn{3}{|c|}{51400 pieces } & \multicolumn{3}{|c|}{$415 \mathrm{~m}^{3}$} & \multicolumn{3}{|c|}{166600 pieces } \\
\hline$k_{i d}$ & 98 & 98 & 98 & 98 & 98 & 98 & 98 & 98 & 98 \\
\hline$l_{d m}$ & 5 & 18 & 4 & 4 & 24 & 1 & 14 & 44 & 7 \\
\hline$k_{t z}$ & 250 & 250 & 250 & 250 & 250 & 250 & 250 & 250 & 250 \\
\hline$d_{o}-$ last delivery volume & 3800 & 400 & 12400 & 91 & 1 & 415 & 11900 & 1050 & 23800 \\
\hline$l_{s}$ & 30 & 35 & 28 & 8 & 24 & 8 & 28 & 44 & 28 \\
\hline$k_{t w}$ & 0 & 0 & 40 & 0 & 0 & 40 & 0 & 0 & 40 \\
\hline$l_{d b}$ & 0 & 0 & 172 & 0 & 0 & 35 & 0 & 0 & 303 \\
\hline$c_{j}$ & 2,55 & 2,55 & 2,55 & 176 & 176 & 176 & 0,65 & 0,65 & 0,65 \\
\hline$p$ & 0,24 & 0,24 & 0,24 & 0,24 & 0,24 & 0,24 & 0,24 & 0,24 & 0,24 \\
\hline$s_{c}$ & 0 & 0 & 6500 & 0 & 0 & 207,5 & 0 & 0 & 11900 \\
\hline$s$ & 5950 & 1500 & 150 & 54 & 9 & 5,9 & 5950 & 1925 & 275 \\
\hline$k_{k z}$ & 10000 & 10000 & 10000 & 10000 & 10000 & 10000 & 10000 & 10000 & 10000 \\
\hline$l_{b z}$ & 0 & 0 & 0 & 0 & 0 & 0 & 0 & 0 & 0 \\
\hline$K_{m}$ & 0 & 0 & 2000 & 1000 & 1000 & 2000 & 0 & 0 & 2000 \\
\hline$d$ & 11900 & 3000 & 13000 & 108 & 18,0 & 415 & 11900 & 3850 & 23800 \\
\hline$p_{u}$ & 0,25 & 0,25 & 0,25 & 0,3 & 0,3 & 0,3 & 0,2 & 0,1 & 0,2 \\
\hline$d_{u}$ & 3800 & 51400 & 0 & 0 & 415 & 0 & 0 & 0 & 0 \\
\hline$K_{L}$ & 11631 & 11432 & 20342 & 5673 & 9732 & 14512 & 9300 & 15612 & 23705 \\
\hline$K_{B}$ & 100725 & 131070 & 98303 & 51128 & 73040 & 51128 & 86632 & 97461 & 86632 \\
\hline$K$ & 112356 & 142502 & 118644 & 56801 & 82772 & 65640 & 95932 & 113073 & 110337 \\
\hline
\end{tabular}


Table 2. Results of supply cost simulation [20]

\begin{tabular}{|c|c|c|c|c|c|c|}
\hline \multirow{2}{*}{ Cost type } & \multirow{2}{*}{$\begin{array}{c}\text { Centralised } \\
\text { supply cost } \\
\text { [zł] }\end{array}$} & \multicolumn{4}{|c|}{ Individual supply cost $[\mathrm{zt}]$} & \multirow{2}{*}{$\begin{array}{l}\text { Advantage of } \\
\text { logistic centre } \\
\text { services [zł] }\end{array}$} \\
\hline & & Contractor 1 & Contractor 2 & Contractor 3 & Total & \\
\hline 1 & 2 & 3 & 4 & 5 & $3+4+5$ & $(3+4+5)-2$ \\
\hline Material direct cost & 540960,00 & 193660,00 & 38640,00 & 308660,00 & 540960,00 & 0 \\
\hline Buying cost & 3627,45 & 2469,87 & 1478,40 & 2952,40 & 6900,67 & 3273,20 \\
\hline Price discount & $-51744,75$ & $-5809,80$ & 0,00 & $-15433,00$ & $-21242,80$ & 30501,90 \\
\hline Cost of carriage & 26460,00 & 12630,00 & 2520,00 & 20130,00 & 35280,00 & 8820,00 \\
\hline Internal transport & 1563,72 & 0,00 & 0,00 & 0,00 & 0,00 & $-1,563,70$ \\
\hline Capital in stocks & 13176,28 & 2117,09 & 648,46 & 2843,90 & 5609,45 & $-7566,80$ \\
\hline Total & 534042,70 & 205067,16 & 43286,86 & 319153,29 & 567507,32 & 33464,62 \\
\hline
\end{tabular}

Both models assume deliveries in the amount of economic order quantity and storing the material on the building site as proved in Example 1 to be the best solution under assumptions mentioned above. Table 2 presents results of the simulation. The results indicate that using the common supplier for this particular material (and assumed conditions) allows the customer (the contractor) to save up to $6 \%$ on logistic costs.

In case of the "centralised procurement" method, the logistic centre (or other entity offering logistic services) is able to negotiate better discounts and may be able to offer lower buying costs. On the other hand, average inventories are heavier and the cost of frozen capital grows. There are also additional costs of internal transport from the logistic centre to its customers.

The advantages of logistic centres are not limited to cost reduction. The quality of service may be also higher due to specialisation of logistic organisations. Logistic centres should be able to co-ordinate and optimise their transport and therefore reduce the transport infrastructure loads (important in cities) and limit air pollution.

\section{Planning construction project logistics}

Example 2 illustrates that integrating logistic processes of a project may lead to cost reduction. This is due to the economies of scale and synergetic effect.

Taking over logistic services rendered to many contractors by one organisation is only one of the possibilities of complex approach to project logistics and profiting from it in terms of efficiency. There are impotrant logistic tasks and processes that occur at every stage of a construction project [8]. These basic logistic tasks are listed below according to the project phase:

\section{Phase 1 - Initiation - programming}

- Checking the concept from the point of logistics

- Preparation of logistic guidelines for site planning

- Preparation of logistic strategy for project management
Phase 2 - Design

Preparation of:

- logistic guidelines for the design

- analysis of alternative structural designs and materials utilisation

- material requirement specification

- feasibility study of logistic concepts

- execution design

- logistic guidelines for tender preparation

- quality system of logistic services

\section{Phase 3 - Planning}

Preparation of:

- schedules and charts of labour and equipment utilisation, subcontractors work and material consumption

- logistic concept of the building site

- design of site installation and disassembly

- guidelines for purchase or lease of machinery

- selection of suppliers

- plans of logistic processes (models and methods of control)

- Asessment of logistic service efficiency and impact on environment

- Planning and placing orders, scheduling deliveries

- Waste management planning

- Planning information flows management and methods

\section{Phase 4 - Execution}

- Work progress monitoring

- Schedules and plans updating

- Adjusting orders to current demand for resources (workforce, materials, plant, subcontractors)

- Creating operation centres to serve contractors

- Planning and coordinating horizontal and vertical transport on the site

- Planning and co-ordinating deliveries, loading, unloading and warehousing, distributing deliveries to contractors

- Implementing logistic service quality standards

- Recording feedback information on the effects of implementing integrated logistic systems 
- Managing waste

- Managing information flows, documentation, implementation and maintenance of the information system

\section{Phase 5 - Commissioning}

- Dismantling of site installation

- Managing information flows, documentation

The analysis of the whole project's life cycle indicates that there are as many logistic tasks at initial stages of programming, designing and planning as in the execution phase. Experience prompts that careful consideration and well developed logistic concepts allow effective execution of projects and reduction of total project outlay and/or quality improvement.

Such a broad scope of logistic tasks would require entrusting them to a professional, especially as the project is to be executed under challenging external constraints. Such a professional becomes important actor among the participants of the project (Fig 7).

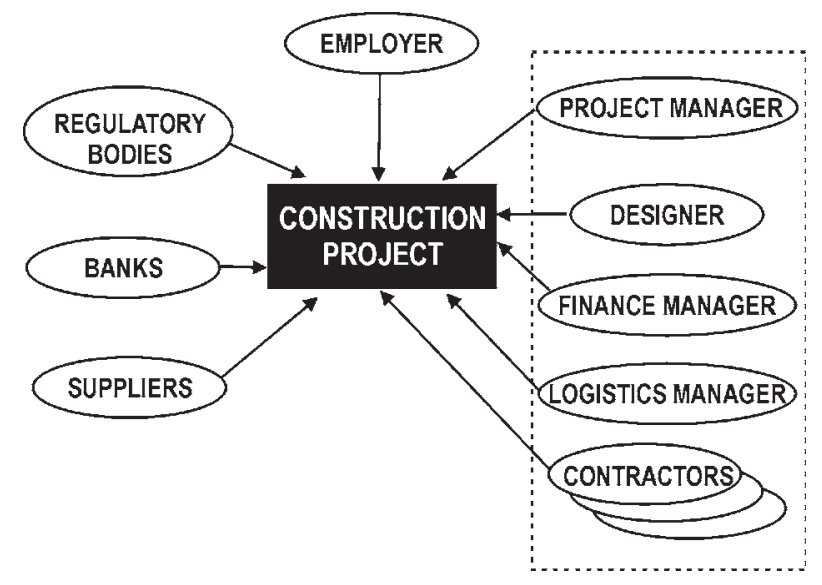

Fig 7. Participants of the construction project

In practice of some types of procurement systems such as construction management, or design-build with contract engineer [23], there is a special unit in the project management structure to control and plan logistic processes through all phases of the project. Integrated logistics for the whole project means the possibility of optimising supply chains and co-ordinating deliveries, which is significant for great construction projects that involve many contractors working in confined space.

To illustrate the necessity and benefits from integrating logistic responsibilities under one management, the currently largest project in Poland, Złote Tarasy business centre, may serve as an example. The works are being carried out in the very centre of Warsaw by a general contractor and a large number of subcontractors. Due to location in the centre of a large city and scope of works requiring massive deliveries of materials, equipment and machinery, centralised logistic management unit was undispensable and was established by the general contractor within his management system. Also the economies of scale were exploited: most of the resources needed by subcontractors are being ordered directly by the general contractor - a large and renowned company able to negotiate good terms of payment. This is done to the benefit of the general contractor, the project, the subcontractor whose responsibility is reduced.

In Poland, outsourcing of logistic services occurs in practice quite often, as follows from the survey results presented in Chapter 3, but mostly during the execution phase of the project.

An interesting example of complex approach to construction project logistics was the Potsdamer Platz Project in Berlin [1, 2]. Planning and designing its logistics and establishing the Logistic Centre allowed the contractors to avoid technical and organisational problems and also to protect environment, reduce project completion time and cost and minimise inconvenience of massive construction works for the inhabitants of the city [2].

\section{Summary}

The results of the quantitative analysis of supply logistics models in the aspect of costs presented in the paper indicates that there exist methods to reduce expenses. One of the bases of potential savings is integration of logistic processes and benefiting from the economies of scale. The choice of supply model and method of material flow control also influence cost levels. Another effective way to make a project cost-effective is to co-ordinate and plan logistic processes involving each project participant on every stage of the project [22]. An efficient logistic plan is to consider relations of all project actors starting from the employer, designers and contractors to financial institutions and regulatory bodies.

It is clear that there is no typical or best system of project's logistics. In a longer perspective each system must be readjusted to the external conditions or even completely reconstructed. New effective solutions have to be implemented to reach the expected efficiency of a project. Considering supply system, which is only one of many elements of project logistics, the following models are possible:

- independent supply chains for individual contractors, where selection of suppliers, supply planning and scheduling is the duty of each contractor,

- centralised supply system managed by general contractor or other party managing the whole project, by means of own logistic department,

- centralised supply system managed by an external logistic company, either existing as an independent business organisation or created to serve the project,

- combination of the above.

Supply systems based on independent chains or services of an external logistic company are possible in any type of project delivery systems. In case of delivery systems with a general contractor or other party that disposes of necessary logistic resources, it is reasonable to use them to create and manage the whole project's supply system. Such party benefits directly from any im- 
provement of logistics. Transferring responsibility for supplies on many subcontractors may result in conflicts on the building site, work stoppage, excessive expenses and delays.

It should be emphasised that creating logistic guidelines of a project at its early stages of planning and then a design of integrated logistic service to the project may help find ways of making the project cost effective and to avoid overlooking important constraints.

\section{References}

1. Baumgarten, H. Successes of future-oriented logistics of the building site (Erfolge mit zukunftsorientierter Baustellenlogistik), Bereich Logistik, Technische Universität Berlin, Berlin, 1998 (in German).

2. Baumgarten, H.; Penner, H. The logistics of the Potsdamer Platz building site (Baustellenlogistik Potsdamer Platz), Technische Universität Berlin, Fachbereich Wirtschaft und Management, Berlin, 1997 (in German).

3. Buszko, A. The models of cooperating logistic organisations (Modele współpracy przedsiębiorstw logistycznych), Gospodarka materiatowa i logistyka, 8 (2003), p. 15-20 (in Polish).

4. Buszko, A. Changes in material supply logistics of construction companies in years 1992-2002 (Zmiany w logistyce dostaw materiałów dla wykonawczych firm budowlanych w latach 1992-2002), Gospodarka materiałowa i logistyka, 4 (2003), p. 2-7 (in Polish).

5. Cheng, E. W. L.; Li, H.; Love, P. E. D.; Irani, Z. An ebusiness model to support supply chain activities in construction. Logistics Information Management, Vol 14, No 1/ 2, 2001, p. 68-77.

6. Childerhouse, P.; Lewis, J.; Naim, M.; Towill, D. R. Reengineering a construction supply chain: a material flow control approach. Supply Chain Management. An International Journal, Vol 8, No 4, 2003, p. 395-406.

7. Cigolini, R.; Cozzi, M.; Perona, M. A new framework for supply chain management. Conceptual model and empirical test. International Journal of Operations \& Production Management, Vol 24, No 1, 2004, p. 7-41.

8. Croom, S.; Romano, P.; Giannakis, M. Supply chain management: an analytical framework for critical literature review, European Journal of Purchasing \& Supply Management 6 (2000), p. 67-83.

9. Dainty, A. R. J.; Briscoe, G. H.; Millett, S. J. New perspectives in construction supply chain integration. Supplly Chain Management. An International Journal, Vol 6, No 4, 2001, p. 163-173.

10. Hoover, W. E.; Eloranta, J. E.; Holmstrom, J.; Huttunen, K. Managing the Demand-Supply Chain. Value Innovations for Customer Satisfaction. John Wiley \& Sons, New York 2001.

11. Kasperek, M.; Lewtak, W. Analysis of logistic processes impact on execution cost of construction project (Analiza wpływu procesów logistycznych na koszty realizacji przedsięwzięć budowlanych), Msc thesis, Politechnika Lubelska, 2004 (in Polish).

12. Kumaraswamy, M.; Palaneeswaram, E. Humphreys P. Selection matters in construction supply chain optimisation. International Journal of Physical Distribution \& Logistics Management, Vol 30, No 7/8, 2000, p. 661-680.

13. Love, P. E. D.; Irani, Z.; Edwards, D. J. A seamless supply chain management model for construction. Supply Chain Management. An International Journal, Vol 9, No 1, 2004, p. 43-56.

14. Matthews, J.; Pellew, L.; Phua, F. and Rowlinson, S. Quality relationships: partnering in the construction supply chain. International Journal of Quality \& Reliability Management, Vol 17, Nos 4/5, 2000, p. 493-510.

15. Michlowicz, E. Foundations of industrial logistics (Podstawy logistyki przemyslowej) AGH Uczelniane Wydawnictwa Naukowo-Dydaktyczne, Kraków, 2002 (in Polish).

16. Pheng, L. S.; Chuan, Ch.J. Just-in-Time management of precast concrete components. Journal of Construction Engineering and Management, Nov/Dec 2001, p. 494-501.

17. Poortman, E. R.; Bons, H. N. M. Information for the management of the building-materials flow. Engineering Construction and Architectural Management, 1/2 (1994), p. $139-140$.

18. Serra, S. M. B.; Oliveira, O. J. Development of the logistics plan in building construction. System-based vision for strategic and creative design, Bontempi (ed.), Lisse, Swets \& Zeitlinger, 2003, p. 75-80.

19. Sobotka, A. Identification of logistic systems models in construction company. Archives of Civil Engineering, XLVII, No 1, 2001.

20. Sobotka, A. Simulation modelling for logistics re-engineering in the construction company. Construction Management and Economics, 18 (2000), p. 183-195.

21. Sobotka, A.; Czarnigowska, A.; Stefaniak, K. Logistics of construction projects, Proceedings of the 8th International Conference Modern Building Materials, Structures and Techniques, Vilnius, Lithuania, 2004.

22. Stevans, G. C. Integrating the supply chain. International Journal of Physical Distibution and Materials Management, Vol 19, No 8 (1989), p. 3-8.

23. Tenah, K. A. Existing and emerging delivery systems for construction projects. System-based vision for strategic and creative design, Bontempi (ed.), Lisse, Swets \& Zeitlinger, 2003, p. 151-156.

24. Voordijk, H. The changing logistical system of the building materials supply chain. International Journal of Operations \& Prooduction Management, Vol 20, No 7, 2000, p. 823-841.

25. Voordijk, H. Precondiction and dynamics of logistics networks in the Dutch building industry. Supply Chain Management, Vol 4, No 3, 1999, p. 145-154.

26. Vrijhoef, R.; Koskela, L. The four roles of supply chain management in construction. European Journal of Purchasing \& Supply Management, 6 (2000), p. 169-178. 
STATYBOS PROJEKTŲ LOGISTIKOS PLANAVIMUI TAIKOMŲ TIEKIMO SISTEMOS MODELIŲ ANALIZE்

A. Sobotka, A. Czarnigowska

\section{Santrauka}

Apžvelgti Lenkijos rangovų tiekimo procesai, nagrinėjamos statybos projektų logistikos problemos. Aprašomi logistikos sistemų vystymo variantai. Tiekimo procesų logistikos modeliavimas leidžia sumažinti išlaidas. Parodyta, kad ankstyvosiose projektavimo stadijose tikslinga suformuluoti svarbiausius logistikos principus ir kurti integruotą logistinio aptarnavimo centrą. Šios priemonès leidžia rasti papildomų būdų statybos projektų efektyvumui didinti.

Raktažodžiai: logistika, išlaidos medžiagoms įsigyti, statybos projektas, tiekimo sistema, logistikos centras.

Anna SOBOTKA. Assoc Professor at Lublin University of Technology (Poland), Faculty of Civil and Sanitary Engineering. $\mathrm{PhD}$ and DSc in construction technology and organisation. She teaches in the areas of technology, planning and organisation of construction projects and construction management. Her research focuses on computer integrated manufacturing, inteligent simulation system, logistics of construction projects and sustainable construction.

Agata CZARNIGOWSKA. Teaching and research assistant at the Lublin University of Technology (Poland), Faculty of Civil and Sanitary Engineering. She teaches construction economics and project planning. Her research includes project management, public-private partnerships, cost and value management. 